\title{
BARRETO, Benito. Toque de silêncio em Vila Rica. Ilustrações de Sebastião Januário. Belo Horizonte: Casa de Minas, 2011. $351 \mathrm{p}$.
}

Edgard Pereira Universidade Federal de Minas Gerais

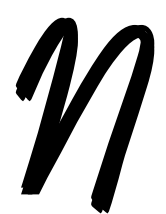

ascido em 1929, Benito Barreto tem sua trajetória reconhecida e significativa fortuna crítica, pela tetralogia Os Guaianãs, composta pelos romances Plataforma vazia (1962), Capela dos homens (1968), Mutirão para matar (1974) e Cafaia (1975). Em 1986, a editora Mercado Aberto, de Porto Alegre, reeditou a tetralogia em dois tomos.

Último romance de Benito Barreto, Toque de silêncio em Vila Rica é o terceiro título da monumental Saga do Caminho Novo, construída tendo por base a Inconfidência Mineira. Projeto arrojado, segue os rumos do romance histórico, cujos eventos principais, em suas linhas básicas, mantêm-se caudatários da Historiografia. Por uma feliz confluência, o substrato ficcional tem dupla inscrição na ideia da autonomia: no plano literário, pela moldura árcade que fundamenta a produção dos autores envolvidos (o Arcadismo é tido como o início da gestação da autonomia da literatura brasileira); no plano político, pelo aflorar das ideias de liberdade.

Os pontos de contato e distanciamento entre o romance histórico e a História remontam a Aristóteles, segundo o qual 
cabe ao historiador escrever o acontecimento real, enquanto o romancista preocupa-se com o acontecimento possível. Por natureza, o romance histórico retoma uma herança das biografias clássicas, qual seja a de dar ênfase às ações humanas na esfera pública. Nos relatos de Suetônio e Plutarco, a glória é decorrência de uma vida exemplar em proveito da coletividade. Sem desconsiderar este aspecto, o romance de Benito Barreto mantém uma relativa fidelidade aos fatos históricos, ao dar ênfase à vida íntima e privada das personagens, àquilo que não consta nos documentos. A intenção do narrador é flagrar as personagens no seu enquadramento humano, como indivíduos no seu viver cotidiano, esvaziados da aura historiográfica. Os protagonistas, ainda que inseridos num contexto histórico, são descritos não como dados de um arquivo morto, mas como seres humanos, em sua rede de relações sociais, dotados de crenças, desejos e sonhos. Recriados com os voos da vertiginosa imaginação do escritor, numa concepção de liberdade criativa receptiva à ideia de que a História não passa de um arcabouço linguístico, os eventos narrados mostram-se despojados dos grilhões, resíduos e mofo do passado.

A trama inicia-se num período histórico excepcionalmente conturbado na província das Minas, março de 1789, quando os ecos da queda dos principais vultos da insurreição são conhecidos e sussurrados. Denunciado o movimento, os mais influentes líderes estão presos, à espera de julgamento. Tiradentes, o mais exaltado deles, padece numa masmorra da ilha das Cobras, no Rio de Janeiro, juntamente com Alvarenga, Gonzaga - presos, torturados e incomunicáveis. O coronel Francisco Oliveira Lópes e outros rebeldes estão presos na Casa dos Contratos, em Vila Rica, de propriedade do contratador Rodrigues de Macedo. De origem portuguesa, esta personagem move-se numa nebulosa conduta, em parte fiel à Coroa Portuguesa, de outro lado simpatizante dos ideais revolucionários, por conhecer de perto os abusos do fisco, 
a cobrança do quinto do ouro. Outras prisões sucedem-se, numa atmosfera de medo e opressão, tais como a do Cônego Luís Vieira e a do intocável Cláudio Manoel da Costa, poeta e advogado ilustre. $\mathrm{O}$ viver entre opostos, a ambiguidade assumida como artimanha de sobrevivência ou hipócrita sabedoria acompanha o comportamento de comerciantes e poderosos. A proverbial conduta, moldada pela esperteza, uma batida no cravo, outra na ferradura. Os mais tensos e dramáticos movimentos, narrados com surpreendente efeito de realidade e forte lastro emocional, giram em torno da prisão e assassinato por enforcamento de Cláudio Manoel, considerado peça fundamental da Inconfidência, pela extensa atuação a serviço dos interesses portugueses, tanto por força dos altos cargos ocupados, como pelo suposto apoio aos rebeldes. Relevem-se os seus conflitos de consciência, dividido entre a cumplicidade com os amigos e a dívida com a Metrópole, de que muitas vezes se beneficiara. $\mathrm{O}$ Visconde de Barbacena, tirano implacável, senhor de castigos e de armadilhas, reina de forma autoritária e devassa, entre gracejos de salão e brutais desmandos. Como pano de fundo lutuoso, os vultos sombrios das chamadas viúvas da Inconfidência, Hipólita Jacinto, Bárbara Heliodora e Dorotéia de Seixas (esta por força de delirante transmutação, no papel de uma doidivanas Marília de Dirceu) rodam e rondam as ruas desertas de Vila Rica, assustando e conclamando o povo, de forma pungente e grotesca, a apoiar os revoltosos.

Com tais ingredientes, Benito Barreto constrói um comovente relato da construção da ideia de autonomia em nossas terras, fantasia audaciosa de intelectuais, assumida por camadas populares, que aos poucos acabam se intimidando, diante do terror:

(...) aquela mesma e grave estória da qual, assustado, falava há pouco o General Governador e, em seguida, a confirmando, o Motta a Rodrigues de Macedo, seu patrão, 
na Casa dos Contratos: das hordas sem rumo de centenas de garimpeiros, montados e armados, talando os Gerais e bordejando as vilas, em busca de um contato com os revoltosos do Tiradentes ou, pelo menos, de quem tenha notícia deles ou a eles represente... (p.150).

À margem de condutas interesseiras, um ano após regressar da Europa, enfeitiçado pelos ideais libertários, o engenheiro de minas, José Álvares Maciel, antes de ser preso, desesperado, tenta fugir:

Ah, vontade de ficar, de ser aqui o que é preciso e se precisa tanto! de poder assumir, de pleno amor e peito aberto, a pátria e o chão, esse chão de Minas, tão seu...onde eu nasci e fui menino, mas o luso diz que é seu, colônia sua, que explora e avilta, de que tira tudo e a nós, seus filhos, escraviza e prende ou, simplesmente, matam, como a Cláudio Manoel da Costa acabam de matar! (p.288)

Grandiosa construção épica, espraiada tanto espacialmente, ao abranger desde Vila Rica e Sabará às cidades e arraiais mais distantes, como Campanha do Sapucaí e Rio de Janeiro, como alargada também em incontáveis personagens secundárias, descritas em riqueza de detalhes, apurados apelos sensoriais e refinados torneios linguísticos, representativos do contexto histórico. Lançado recentemente, Toque de silêncio em Vila Rica, sem concessões e tom menor, destaca-se como um vigoroso, colorido e diversificado mergulho nos sangrentos idos do final do século dezoito das Gerais. 